\title{
Herpes Genitalis: Diagnosis, Treatment and Prevention
}

\author{
Diagnostik des Herpes genitalis, einschließlich antiviraler Therapie \\ und prophylaktischer Möglichkeiten
}

Author

Affiliation

\section{A. Sauerbrei}

Institut für Virologie und Antivirale Therapie, Konsiliarlabor für HSV und VZV, Universitätsklinikum Jena, Jena, Germany

\begin{abstract}
Key words
- herpes simplex virus

- herpes genitalis

- laboratory diagnostics

- antiviral therapy

- prophylaxis

Schlüsselwörter

- Herpes-simplex-Virus

- Herpes genitalis

- Labordiagnostik

- antivirale Therapie

- Prophylaxe
\end{abstract}

Deutsche Version unter: http://dx.doi.org/ $10.1055 / \mathrm{s}-0042-116494$

\section{Abstract \\ $\nabla$}

Herpes genitalis is caused by the herpes simplex virus type 1 or type 2 and can manifest as primary or recurrent infection. It is one of the most common sexually transmitted infections and due to associated physical and psychological morbidity it constitutes a considerable, often underestimated medical problem. In addition to providing the reader with basic knowledge of the pathogen and clinical presentation of herpes genitalis, this review article discusses important aspects of the laboratory diagnostics, antiviral therapy and prophylaxis. The article is aimed at all health-care workers managing patients with herpes genitalis and attempts to improve the often suboptimal counselling, targeted use of laboratory diagnostics, treatment and preventive measures provided to patients.

\section{Zusammenfassung \\ $\nabla$}

Der Herpes genitalis wird durch Herpes-simplexVirus Typ 1 oder Typ 2 hervorgerufen und kann sich als primäre und rekurrierende Infektion manifestieren. Die Erkrankung gehört zu den häufigsten sexuell erworbenen Infektionskrankheiten und stellt aufgrund ihrer physikalischen und psychosozialen Morbidität ein erhebliches und oft unterschätztes medizinisches Problem dar. In der vorliegenden Übersichtsarbeit werden neben medizinischen Grundkenntnissen zum Erreger des Herpes genitalis und der Erkrankung wesentliche Aspekte der Labordiagnostik, einschließlich antivirale Therapie und prophylaktische Möglichkeiten vermittelt. Der Beitrag wendet sich an alle Mitarbeiter im Gesundheitsdienst, die Patienten mit Herpes genitalis betreuen, und zielt darauf $\mathrm{ab}$, die häufig unzureichende Beratung sowie Maßnahmen bez. einer gezielten Diagnostik, Therapie und Prävention bei den betroffenen Patienten zu verbessern.

antibodies during the first year of life. Current data on seroprevalence in Germany show a rise in anti-HSV-1 IgG to approx. $20 \%$ by the age of $2-3$ years, to $57 \%$ in $10-12$-year-olds, approx. $70 \%$ in $16-18$ year olds and around $80 \%$ in adults aged $28-30$ years [4]. From the age of 40 years and onwards one can assume an HSV-1 seroprevalence of $\geq 85-90 \%$ [5]. Since HSV-2 is mainly transmitted through sexual intercourse infection rates only rise after puberty. In Germany the prevalence of anti-HSV-2 IgG antibodies rises from approx. $3 \%$ in $10-15$-year-olds to $7 \%$ in the age group $16-18$ years, to approx. $14 \%$ in adults [4]. Higher seroprevalences are found internationally among people who regularly change sexual partners and among homosexual men [6]. Numerous studies have shown a significantly higher HSV-2 seroprevalence in women than in men $[4,5]$. As a possible 
reason for this it has been suggested that men have asymptomatic genital HSV-2 infections more often than women, resulting in higher virus transmission rates from men to women [7]. Partial clinical cross-immunity exists between HSV-1 and HSV-2 and as a result, primary genital HSV-2 infection may be asymptomatic in patients with HSV-1 immunity and vice versa. A reduced HSV-1 seroprevalence among young people (adolescents) and adults may be associated with higher numbers of primary HSV-2 or HSV-1 infections due to oral sex. There is published evidence of this in the USA $[8,9]$ but not yet in Germany. Genital HSV-2 infection is associated with an increased risk of HIV infection [10].

\section{Virus Transmission and Infection \\ $\nabla$}

\section{Primary herpes genitalis}

Primary genital infections with HSV-1 and HSV-2 are usually asymptomatic [11]. The classical clinical features consist of macular or papular skin and mucous membrane lesions occurring approx. 4-7 days after sexual contact; these progress to vesicles, pustules and ulcers and can last for up to 3 weeks. [12]. Typical symptoms also include pain, especially painful inflammatory swelling of the vulva in women, burning pain and dysuria. Lymphadenopathy, fever and cervicitis (in women)/proctitis (in men) are relatively common associated symptoms. Genital herpes may manifest atypically, particularly in the female genital tract, making the clinical diagnosis far more difficult. Signs of herpes lesions of the cervix are relatively common in the absence of symptoms, while urethral manifestations are often associated with severe micturition problems.

\section{Recurrent herpes genitalis}

Following the primary eruption the virus establishes lifelong latency in sensory neural ganglions [13]; in the case of primary genital infection the sacral ganglions are mainly involved. From here the virus can reactivate, causing recurrent infection. Viral reactivation is common in the presence of immunogenetic predisposition, though reactivations decrease with increasing age. Numerous physiological and environmental factors such as fever, UV light, menstruation, stress or trauma can function as triggers $[14,15]$. Endogenous viral reactivations may manifest as recurrent herpes genitalis. Recurrences occur in almost every person suffering symptomatic primary herpes genitalis due to HSV-2, in a third of patients frequently (at least 6 times a year) [16]. Recurrent genital HSV-1 infections occur over five times less commonly [17]. Recurrences almost always initially present with prodromal symptoms such as neuralgic symptoms, dysaesthesia or lumbosacral dermatome pain 1-2 days before skin and mucosal lesions erupt [18]. Compared to primary infection, symptoms of recurrence are much less severe and the clinical course shorter [19]. In the experience of the reference laboratory for HSV and VSV of the Institute for Virology and Antiviral Therapy of the University Hospital of Jena, in its advisory capacity, frequent herpes genitalis recurrences particularly affect young women with a high burden of stress in the family and workplace. It must also be taken into account that recurrences themselves can cause high levels of emotional stress [20]. Affected patients and their sexual partners therefore more commonly suffer significant psychosocial problems.

\section{Asymptomatic genital viral shedding}

In the majority of cases endogenous viral reactivation is characterised by asymptomatic genital viral shedding. Most commonly HSV-2 is shed by HSV-2 seropositive patients, and this is the case for almost anyone who is anti-HSV-2 IgG positive [21]. In contrast, HSV-1 shedding is uncommon. These data allow the assumption, with a high level of certainty, that HSV-2 seropositive people should always be regarded as potential virus excretors.

\section{Virus transmission}

People with clinically manifest/apparent herpes genitalis and people who shed HSV asymptomatically can transmit the virus to their sexual partners. This almost always occurs via direct contact during sexual intercourse. In recent years an increased incidence of primary genital HSV-1 infection has been reported in the USA, particularly among adolescence and young adults $[8,9]$. This can most probably be ascribed to oral sex, which is more commonly practiced in this age group. Due to its low environmental stability HSV can only remain infectious for a period of days on moist surfaces [22]. It can therefore be assumed with a high level of certainty that when normal hygiene (including bodily hygiene) is maintained, modes of transmission other than sexual intercourse do not play a significant role. Intrauterine and perinatal viral transmission are the exceptions. Both primary and recurrent HSV infection in pregnant women can result in intrauterine viral transmission and congenital HSV infection, although the incidence is low at just $5 \%$ of all HSV infections in newborns [23]. The clinical consequences of fetal infection described include abortion, stillbirth or other congenital manifestations usually including skin and eye lesions and/or neurological symptoms [24]. The highest risk of fetal infection is during the first 20 weeks of pregnancy, and with primary maternal HSV-2 infection. Viral transmission to the child via the mother's genital tract during labour is regarded as the most common cause of neonatal HSV infection; of these infections $70-85 \%$ are caused by HSV-2 [25]. The incidence in the USA is quoted at 5 to 31 per 100000 live births with a worse prognosis for HSV-2 infection compared to HSV-1 [23]. There are no data available on the incidence of neonatal HSV infection in Germany. The highest risk is with perinatal maternal primary HSV infection, however most neonatal infections occur around the birth in the presence of asymptomatic genital tract viral shedding $[23,26]$. Disease manifests as localised infection of the skin, eyes and mucous membranes, CNS infection or disseminated systemic infection [27].

\section{Laboratory Diagnostics \\ $\nabla$}

\section{Sample submission}

Herpes simplex virus-containing samples must be transported as UN 3373 category B, risk group 2 hazardous substances [22]. The primary vessel containing the patient sample must be sent in a covering tube within a labelled transport container (cardboard box) with adsorbing material. In general samples can be sent at room temperature unless the material is being sent for virus isolation, in which case cooling is recommended.

\section{Virus detection}

The laboratory diagnosis of acute genital HSV infection or asymptomatic virus shedding is made via direct viral detection ( Table 1). The method of choice is demonstration of viral genomes in skin or mucous membrane swabs using the polymerase chain re- 
Table 1 Methods to detect HSV and HSV-specific antibody.

\begin{tabular}{|c|c|c|}
\hline Principle & Method & Comments \\
\hline Viral DNA detection & Polymerase chain reaction (PCR) & $\begin{array}{l}\text { Examination material: vesicle content in virus transport medium with special swabs, } \\
\text { liquor, tissue sample, bronchoalveolar lavage, EDTA blood, amniotic fluid, intraocular fluid } \\
\text { - Commercially available, for routine use }\end{array}$ \\
\hline Virus isolation & $\begin{array}{l}\text { Cultivation in cell cultures, } \\
\text { detection/typing using } \\
\text { monoclonal antibodies }\end{array}$ & $\begin{array}{l}\text { Examination material: vesicle content in virus transport medium with special swabs, } \\
\text { tissue sample, bronchoalveolar lavage } \\
\text { Specialised test }\end{array}$ \\
\hline Viral antibody detection & $\begin{array}{l}\text { Immunofluorescence test } \\
\text { with monoclonal antibodies }\end{array}$ & $\begin{array}{l}\text { Examination material: cell-rich vesicle content in virus transport medium } \\
\text { with special swabs, tissue sample } \\
\text { L Limited sensitivity and specificity, routine use }\end{array}$ \\
\hline $\begin{array}{l}\text { Detection of type-specific } \\
\text { and non-type-specific } \\
\text { antibodies }\end{array}$ & $\begin{array}{l}\text { Enzyme-linked immunosorbent } \\
\text { assay (ELISA) }\end{array}$ & $\begin{array}{l}\text { Determination and differentiation of I classes (lgG, IgM) in serum, plasma and liquor } \\
\text { - Detection of viral type-specific antibodies against viral glycoproteins ( } \mathrm{gG}-1, \mathrm{gC}-1, \mathrm{gG}-2 \text { ) } \\
\text { - Detection of non-type-specific viral antibodies with total viral antigen determination } \\
\text { from HSV-1 or HSV-2 infected cell cultures } \\
\text { - Commercially available, automated, routine use }\end{array}$ \\
\hline $\begin{array}{l}\text { Detection of non-type- } \\
\text { specific antibodies }\end{array}$ & $\begin{array}{l}\text { Indirect immunofluorescence } \\
\text { antibody test (IFAT) }\end{array}$ & $\begin{array}{l}\text { Detection and differentiation of Ig classes (IgG, IgM) in serum, plasma and liquor } \\
\text { - Commercially available, experience required for interpretation, specialised test }\end{array}$ \\
\hline $\begin{array}{l}\text { Detection of type-specific } \\
\text { antibodies }\end{array}$ & Immunoblot & $\begin{array}{l}\text { Qualitative determination of viral type-specific lgG antibodies against viral glycoproteins } \\
(\mathrm{gG1}, \mathrm{gG} 2) \text { in serum } \\
\text { - Commercially available, partly automated, specialised test }\end{array}$ \\
\hline
\end{tabular}

action (PCR) [28]. The content of vesicles provides the best swab material. The sample should be sent in physiological saline solution or viral transport medium. In the presence of complications involving other organs the examination of liquor, tissue samples, bronchoalveolar lavage, amniotic fluid, intraocular fluid, serum or EDTA blood should be considered. The PCR test should be able to differentiate between HSV-1 and HSV-2 [29] and various inhouse assays and commercially available kits are used [30]. The sensitivity of PCR is quoted at $\geq 98 \%$ independent of the qualitative or quantitative method used, the specificity at almost $100 \%$ [30]. Considering these data and the reduced stability of viral DNA when samples are stored for a few days at temperatures over $20^{\circ} \mathrm{C}$, a negative PCR by no means entirely excludes HSV infection. Current guidelines thus recommend starting antiviral treatment when typical herpes genitalis symptoms are present regardless of laboratory results [31,32]. Alternatively, acute genital HSV infection or asymptomatic viral shedding can be diagnosed by growing the virus in tissue cultures, whereby typing of viral isolates is performed by immunofluorescence using appropriate fluorescein labelled HSV serotype-specific monoclonal antibodies. Virus isolation is a sensitive method of detecting HSV since both HSV-1 and HSV-2 grow well in various cell types, such as diploid human embryonic fibroblasts or permanent Vero cells and HEp-2 cells. However in view of its higher sensitivity [33], PCR is rightly regarded as the gold standard of diagnosis in many laboratories. Virus isolation continues to be recommended as an alternative method for diagnosis of genital herpes [31]. Direct HSV antigen detection using commercially available immunofluorescence tests is a commonly used and economic method of diagnosis that provides results within hours; sensitivity and specificity are however limited $[34,35]$. It must be remembered that direct viral detection does not differentiate between primary and recurrent infection or asymptomatic virus shedding.

\section{Antibody detection}

The detection of virus-specific antibodies for confirming HSV infection is widely used in clinical practice. One should however be aware of the limited value of serology results. HSV serology ( Table 1) is mainly useful for confirming seroconversion fol- lowing primary infection, through demonstration of IgG. This can be of particular value in the diagnosis of HSV-2 infections in the context of antenatal care. Confirming seroconversion is also possible by demonstrating type-specific IgG antibodies, and since HSV-1 and HSV-2 are so closely related this is only possible using ELISA/immunoblot on the basis of HSV-1 gG-1 or gC-1, and HSV$2 \mathrm{gG}-2[2,3]$. When interpreting results it is important to consider that partial cross-immunity exists between HSV-1 and HSV-2. The importance of HSV type-specific IgG is mostly that it allows rapid, reliable and economical identification of HSV-2 carriers and potential virus shedders $[31,36]$. Thus a patient in whom anti-HSV-2 IgG is detected can be considered a potential virus shedder and transmitter who may also suffer from anogenital HSV infection. If an initial serum sample is available from the early stage of a herpes genitalis infection, primary and recurrent infections can be differentiated from one another through the detection of virus type-specific DNA by PCR in combination with virus type-specific $\operatorname{IgG}$ [37]. As an example, this means that when HSV-2 is detected on genital swab in a pregnant woman, primary genital herpes can be differentiated from a recurrence up to a few weeks before delivery using HSV type-specific IgG. This differentiation is of great significance, since the risk of severe neonatal HSV infection is many times higher following primary infection than with recurrent infection. Although HSV type-specific antibody tests have been commercially available for approx. two decades they are used seldom in Germany despite the above mentioned advantages, and most laboratories only offer non typespecific HSV antibody tests [38,39]. Avidity testing can also assist in differentiating between primary and recurrent infections although to date experience with this method is limited [40]. Negative anti-HSV IgG excludes recurrent HSV infection. Table 2 provides a summary of virology and serology findings for the laboratory diagnosis of HSV infections with or without genital lesions and for asymptomatic viral shedding.

The detection of anti-HSV IgM is of limited significance for early confirmation of acute HSV infection. False positive IgM results are possible due to cross-reactivity with other herpes viruses, e.g. the varicella-zoster virus. Confirmation of acute HSV infection is only possible using non type-specific HSV IgM tests that have high 


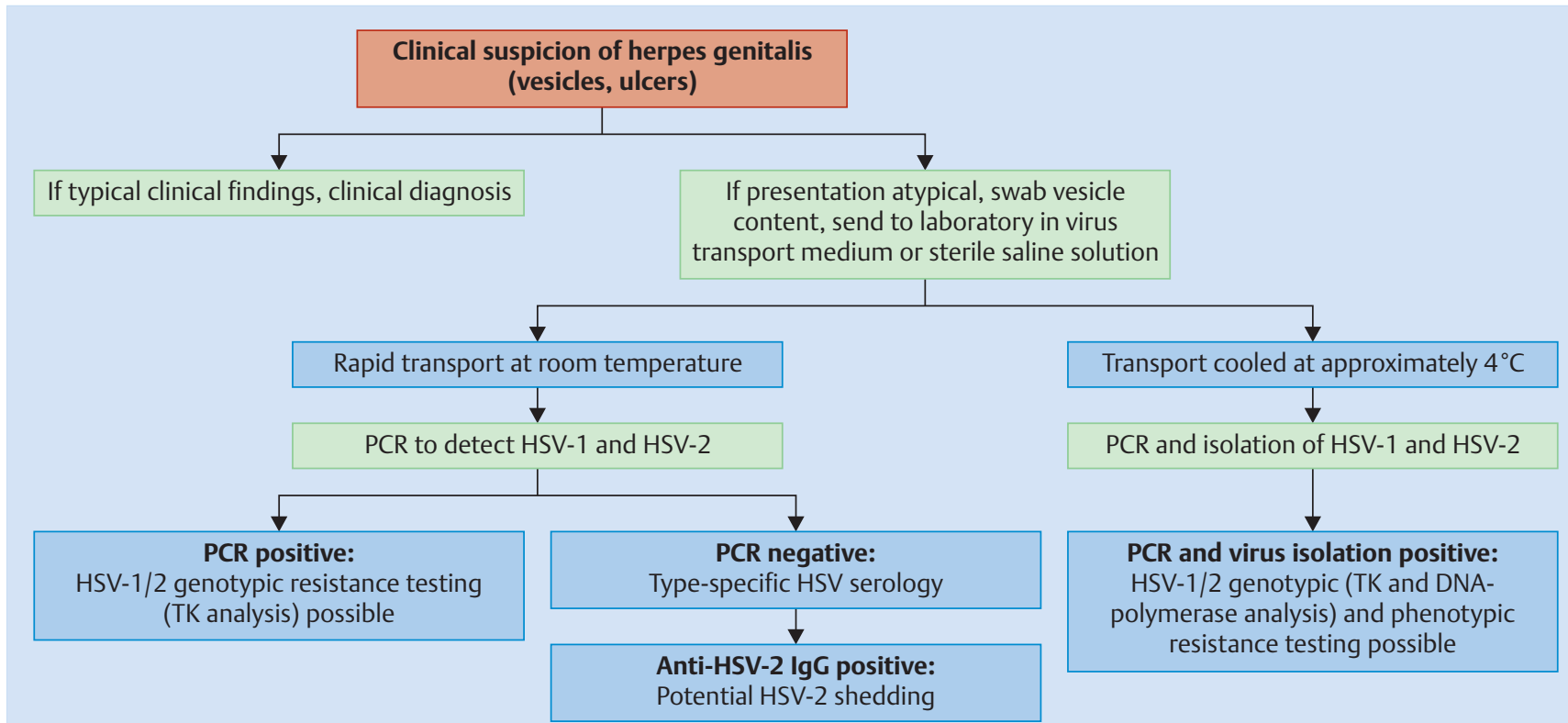

Fig. 1 Recommended viral diagnostic algorithm for herpes genitalis. PCR - polymerase chain reaction, TK - thymidine kinase.

Table 2 HSV laboratory findings and correlating herpes genitalis symptoms.

\begin{tabular}{|c|c|c|c|c|c|c|}
\hline \multirow[t]{3}{*}{ Clinical presentation } & \multicolumn{3}{|c|}{ HSV serology } & \multicolumn{2}{|l|}{ PCR } & \multirow[t]{3}{*}{ Interpretation/Infection status } \\
\hline & HSV-1/ & HSV-1 & HSV-2 & HSV-1 & HSV-2 & \\
\hline & $2 \lg G$ & IgG & IgG & & & \\
\hline \multirow[t]{4}{*}{ Primary herpes genitalis } & neg. & neg. & neg. & pos. & neg. & acute HSV-1 infection \\
\hline & pos. & neg. & pos. & pos. & neg. & acute HSV-1 infection, latent HSV-2 \\
\hline & neg. & neg. & neg. & neg. & pos. & acute HSV-2 infection \\
\hline & pos. & pos. & neg. & neg. & pos. & acute HSV-2 infection, latent HSV-1 \\
\hline \multirow{4}{*}{$\begin{array}{l}\text { Recurrent herpes } \\
\text { genitalis }\end{array}$} & pos. & pos. & neg. & pos. & neg. & recurrent HSV-1 infection (recurrence) \\
\hline & pos. & pos. & pos. & pos. & neg. & recurrent HSV-1 infection, latent HSV-2 \\
\hline & pos. & neg. & pos. & neg. & pos. & recurrent HSV-2 infection (recurrence) \\
\hline & pos. & pos. & pos. & neg. & pos. & recurrent HSV-2 infection, latent HSV-1 \\
\hline \multirow{8}{*}{$\begin{array}{l}\text { No genital herpes } \\
\text { lesions }\end{array}$} & neg. & neg. & neg. & neg. & neg. & seronegativity, susceptibility \\
\hline & pos. & pos. & neg. & neg. & neg. & previous HSV-1 infection (latent HSV-1) \\
\hline & pos. & neg. & pos. & neg. & neg. & previous HSV-2 infection (latent HSV-2) \\
\hline & pos. & pos. & pos. & neg. & neg. & previous HSV-1 and HSV-2 infection (latent HSV-1 and HSV-2) \\
\hline & pos. & pos. & neg. & pos. & neg. & asymptomatic shedding of HSV-1, previous HSV-1 infection (latent HSV-1) \\
\hline & pos. & neg. & pos. & neg. & pos. & asymptomatic shedding of HSV-2, previous HSV-2 infection (latent HSV-2) \\
\hline & pos. & pos. & pos. & pos. & neg. & $\begin{array}{l}\text { asymptomatic shedding of HSV-1, previous HSV-1 and HSV-2 infection } \\
\text { (latent HSV-1 and HSV-2) }\end{array}$ \\
\hline & pos. & pos. & pos. & neg. & pos. & $\begin{array}{l}\text { asymptomatic shedding of HSV-2, previous HSV-1 and HSV-2 infection } \\
\text { (latent HSV-1 and HSV-2) }\end{array}$ \\
\hline
\end{tabular}

sensitivity and specificity [41]. It must however be noted that the positive predictive value of anti-HSV IgM is low, and that it does not allow differentiation between primary and recurrent infection. Although IgM is usually positive following primary infection it can also be positive in the context of recurrence, independent of clinical symptoms. The rather unreliable measurement of HSV type-specific IgM antibodies should be avoided in clinical practice [41]. 0 Fig. 1 provides a summary of the recommended viral diagnostic algorithm for herpes genitalis.

\section{Antiviral Therapy}

\section{$\nabla$}

\section{Standard treatment}

- Table 3 gives an overview of antiviral drugs and dosages for the treatment of herpes genitalis according to current guidelines [31, $32,42,43]$. Standard first-line drugs include acyclovir, valacyclovir and famciclovir. The specific antiviral action of these acyclic nucleoside analogues [44] is based on their phosphorylation to monophosphate form by thymidine kinase (TK), the key enzyme of HSV-1 and HSV-2, with subsequent phosphorylation via di- to triphosphate form by cellular enzymes. The triphosphate nucleoside analogues inhibit and fixate the viral DNA polymerase by being incorporated into the growing DNA chain as "false" enzyme 
Table 3 Antiviral treatment of herpes genitalis.

\begin{tabular}{|c|c|c|c|c|}
\hline Condition/type of treatment & Acyclovir & Valacyclovir & Famciclovir & Foscarnet \\
\hline \multirow[t]{2}{*}{ Primary herpes genitalis } & $3 \times 400$ mg p. o. daily, $7-10$ days & $\begin{array}{l}2 \times 500 \mathrm{mg} \text { p. o. daily, } \\
7-10 \text { days }\end{array}$ & $\begin{array}{l}3 \times 250 \mathrm{mg} \text { p. } 0 \\
\text { daily, } 7-10 \text { days }\end{array}$ & \\
\hline & $5 \times 200 \mathrm{mg}$ p. o. daily, $7-10$ days & & & \\
\hline Severe primary herpes genitalis & $\begin{array}{l}3 \times 5 \mathrm{mg} / \mathrm{kg} \text { i. } v \text {. daily, } 5-7 \text { days, } \\
10 \text { days for immunosuppressed }\end{array}$ & & & \\
\hline $\begin{array}{l}\text { Primary herpes genitalis } \\
\text { during pregnancy }\end{array}$ & $5 \times 200 \mathrm{mg}$ p. 0 . daily, 10 days & & & \\
\hline \multirow[t]{3}{*}{$\begin{array}{l}\text { Recurrent herpes genitalis } \\
(<5-6 \text { episodes per year })^{2,3}\end{array}$} & $2 \times 800$ mg p. o. daily, 5 days & $\begin{array}{l}2 \times 500 \mathrm{mg} \text { p. } 0 . \text { daily, } \\
3 \text { days }\end{array}$ & $\begin{array}{l}2 \times 125 \text { mg p.o. } \\
\text { daily, } 5 \text { days }\end{array}$ & \\
\hline & $3 \times 400 \mathrm{mg}$ p. o. daily, 5 days & $\begin{array}{l}1 \times 1000 \mathrm{mg} \text { p. o. daily, } \\
5 \text { days }\end{array}$ & $\begin{array}{l}2 \times 1000 \mathrm{mg} \text { p. } 0 \text {. } \\
\text { daily, } 1 \text { day }\end{array}$ & \\
\hline & $3 \times 800 \mathrm{mg}$ p. o. daily, 2 days & & & \\
\hline $\begin{array}{l}\text { Recurrent herpes genitalis } \\
\text { during pregnancy }\end{array}$ & $\begin{array}{l}3 \times 400 \mathrm{mg} \text { p. } 0 \text {. daily, } 10 \text { days; } \\
\text { preventive: from } 36 \text { th gestational } \\
\text { week to delivery }\end{array}$ & $\begin{array}{l}2 \times 250 \text { mg p. o. daily, } \\
3 \text { days; preventive: } 36 \text { th } \\
\text { gestational week to delivery }\end{array}$ & & \\
\hline $\begin{array}{l}\text { Preventive treatment } \\
\text { before pregnancy }\end{array}$ & $\begin{array}{l}2 \times 400 \text { mg p. o. daily, } \\
\text { max. } 6 \text { months }^{5}\end{array}$ & & & \\
\hline \multirow[t]{2}{*}{$\begin{array}{l}\text { Prophylaxis/viral suppression } \\
\text { ( } \geq 5-6 \text { episodes per year })^{3,4}\end{array}$} & $\begin{array}{l}2 \times 400 \text { mg p. o. daily, } \\
\text { max. } 6 \text { months }{ }^{5}\end{array}$ & $\begin{array}{l}1 \times 500 \text { mg p. o. daily, } \\
\text { max. } 6 \text { months }^{5}\end{array}$ & $\begin{array}{l}2 \times 250 \text { mg p.o. } \\
\text { daily, max. } \\
6 \text { months }\end{array}$ & \\
\hline & $\begin{array}{l}4 \times 200 \text { mg p. o. daily, } \\
\text { max. } 6 \text { months }^{5}\end{array}$ & & & \\
\hline $\begin{array}{l}\text { Recurrent herpes genitalis } \\
\text { with acyclovir resistance }\end{array}$ & & & & $\begin{array}{l}3 \times 40(-80) \mathrm{mg} / \mathrm{kg} \text { i.v. } \\
\text { daily, until clinical improve- } \\
\text { ment (max. } 20 \text { days) }\end{array}$ \\
\hline
\end{tabular}

1 Acyclovir is not licensed for use during pregnancy (off-label use). Use should be avoided particularly before the 15th week of gestation.

2 Mild presentations can also be treated topically with acyclovir or foscarnet. This is not adequate during pregnancy.

3 In immunosuppressed patients (e.g. HIV) higher doses, longer treatment periods and acyclovir i. v. may be necessary.

${ }^{4}$ According to a Cochrane study [45] viral suppression/prophylaxis may already be indicated after at least 4 recurrences per year.

${ }^{5}$ Longer than 6 months in certain settings (e.g. HIV). Prerequisite for viral suppression/prophylaxis: monthly renal and liver laboratory parameters.

${ }^{6}$ Alternative: Cidofovir (5 mg/kg i.v. 1× weekly, later $2 \times$ weekly, off-label use); $1 \%$ foscarnet cream or $1 \%$ cidofovir gel topically.

substrates. In the case of acyclovir/valacyclovir this leads to chain termination, since hydroxyl groups in the 3' position, which are essential for further linkage, are missing. Famciclovir may be incorporated into the growing DNA chain.

Acyclovir is the first choice therapeutic agent for HSV infections, including herpes genitalis. However bioavailability is only 15$30 \%$ with oral administration. Infections of the skin and mucous membranes including herpes genitalis are treated orally in immune competent people. Severe HSV infections, particularly in immunodeficient patients, should be treated with intravenous (i.v.) acyclovir. Acyclovir dosage for the treatment of herpes genitalis is dependant on infection status, immune competence and whether or not the patient is pregnant. If recurrences occur at a rate of over four [45] to six episodes annually [31,32,42,43] longterm treatment to suppress the virus (prophylaxis) should be considered. The benefits of prophylaxis have been proven particularly during pregnancy [46]. Topical acyclovir is only recommended for herpes labialis, herpes keratoconjunctivitis and mildly symptomatic herpes genitalis. Officially acyclovir is not licensed for use in pregnancy, though administration should be avoided particularly before the 15th week of gestation [22]. Results from a pregnancy register published by an acyclovir producer and the Centers for Disease Control and Prevention (USA) [47] as well as results of a retrospective cohort study in Denmark [48] have shown, however, that oral and topical acyclovir do not appear to increase the rate of congenital anomalies. Since these data are not sufficient for general authorisation, particularly in early pregnancy, pregnant patients must be informed about the limited evidence on use in pregnancy (off-label use). Occasional central nervous system side effects have been described following i.v. acyclovir administration and oral acyclovir may produce gastrointestinal side effects. Nephrotoxic substances should not be administrated concurrently and both renal and liver laboratory parameters should be monitored.

Valacyclovir is a prodrug (an L-valyl ester) of acyclovir suitable for oral administration. After ingestion it is converted to acyclovir by the hepatic enzyme valacyclovir hydrolase. Oral valacyclovir has a bioavailability of $54 \%$, achieving active ingredient concentrations three to four times higher than oral acyclovir. This allows increased dose intervals and is associated with better compliance. Valacyclovir is also a standard treatment for herpes genitalis in immunocompetent patients and studies have shown its efficacy for viral suppression and prevention of recurrent herpes genitalis [46]. Valacyclovir is not licensed for antiviral treatment in children and adolescents since its efficacy and safety profiles have not yet been adequately studied in this population. This applies to pregnancy too as there is also little data on its safety in this context [48]. Possible side effects are similar to those of acyclovir.

Famciclovir is the inactive diacetyl ester prodrug of the only topically effective acyclic nucleotide analogue penciclovir, which arises after cleavage of two ester groups in the small bowel and liver. The bioavailability of famciclovir is $77 \%$ after oral application. Famciclovir is also regarded as one of the standard therapeutic agents for herpes genitalis, along with acyclovir and valacyclovir, and is also not licensed for use in children and adolescents, immunosuppressed patients under the age of 25 years or in pregnancy. It should therefore not be used as the treatment of 
choice in pregnancy [49]. In rare cases famciclovir can cause headaches, nausea and confusion.

\section{Alternative treatment options}

Following prolonged use of acyclovir/valacyclovir resistance, including cross-resistance to famciclovir, may develop in up to $5 \%$ of immunosuppressed or HIV positive patients [50,51]. In such cases the pyrophosphate analogue foscarnet ( Table 3 ) is recommended as alternative treatment [35]. Phenotypic and/or genotypic resistance testing should be performed in this situation. Foscarnet inhibits the viral DNA polymerase of numerous DNA and RNA viruses by suppression of pyrophosphate exchange. Since this substance does not need to be metabolised in order to inhibit viral replication it is also effective against TK-negative HSV strains, which are resistant to nucleoside analogues. Important side effects include renal dysfunction and toxin-induced ulcers of the urogenital mucous membranes. Since the 3 times daily i.v. application of foscarnet requires obligatory hospital admission off-label use of cidofovir i.v. once to twice weekly provides an alternative for acyclovir resistant cases ( Table 3). Cidofovir is exclusively licensed for treatment of cytomegalovirus retinitis in the context of HIV, however it is also effective against HSV. Marked nephrotoxicity and a lack of clinical experience with its use in treating HSV infections are significant barriers to the use of cidofovir in clinical practice. In view of the often atypical presentation of genital herpes systemic treatment with foscarnet (or cidofovir) is generally required. Important contraindications include renal dysfunction, hypersensitivity, pregnancy and breastfeeding. When side effects or patient contraindications preclude using systemic foscarnet (or cidofovir) in a patient with acyclovir resistant herpes genitalis, topical application of $1 \%$ foscarnet cream or $1 \%$ cidofovir gel may provide an effective alternative [52].

The helicase blockers, a new class of drug that is currently still in clinical development and testing, may improve the antiviral treatment of herpes genitalis significantly in future. Thus far effective inhibition of HSV replication has been demonstrated in cell cultures, animal models and initial clinical studies without evidence of major side effects. It is thought that helicase blockers bind to the helicase-primase complex, a protein component essential for virus replication, effectively inhibiting DNA synthesis and thus viral replication. Indeed, better results have been achieved in vitro and in vivo than for acyclovir and valacyclovir. For oral pritelivir (BAY 57-1293, AIC316) a significant reduction of clinical symptoms and HSV-2 shedding was shown in herpes genitalis patients [53]. Helicase blockers have also been shown to be effective against acyclovir resistant HSV strains [54].

\section{Resistance testing}

Clinical treatment failure is defined as lack of response to antiviral treatment (usually acyclovir/valacyclovir) within 10 days. In such cases infection with a resistant strain of virus should be suspected [55] and phenotypic and/or genotypic resistance testing performed. These specialised investigations are performed routinely at the HSV and VZV consulting laboratory. In the presence of acyclovir/valacyclovir resistance, which is almost always associated with cross-resistance to famciclovir, alternative treatment with foscarnet is indicated [56]. Phenotypic resistance tests in particular are time consuming, requiring at least 7-10 days, so that when severe resistance is present clinically appropriate changes to treatment should not be delayed until results become available.
In the published literature plaque reduction/cytopathic effect inhibiting tests, dye uptake assays and DNA hybridisation assays have been described, plaque reduction being the most commonly used method [56]. The sensitivity of HSV to virostatic agents can be measured on the basis of inhibition of morphologically induced, virus-specific cell changes; so-called cytopathic effects. By testing the antiviral agent in a geometric dilution series in descending order the agent's mean inhibitory concentration ( $\left.\mathrm{IC}_{50}\right)$, which results in 50\% inhibition of viral replication, is calculated. Largely due to the biological disturbance variable "cell culture" there is currently no internationally standardised cut-off defining resistance. It is therefore necessary to run a control using a TK-positive reference strain along with each test. Most commonly and reliably resistance to nucleoside analogues and cidofovir is assumed when the $\mathrm{IC}_{50}$ of the tested HSV strain is 3 to 5times higher than that of the sensitive control strain $[57,58]$. For foscarnet a set cut-off of $330 \mu \mathrm{M}$ has proven useful [59]. The main advantage of phenotyping is that the interpretation of results is unequivocal, which is why this method continues to be regarded as the gold standard for HSV resistance testing. Disadvantages include the fact that it is time consuming, the high cost of materials needed for isolation and testing of HSV strains in cell cultures, and the lack of standardisation. Phenotypic resistance testing is practically only possible when vesicle or respiratory tract swabs are available from which HSV can be easily isolated. In the majority of cases attempts to isolate the virus from liquor, blood or eye samples are unsuccessful.

Genotypic resistance testing usually involves amplification and sequencing of the TK and DNA polymerase genes [56]. The data are then compared to a sensitive reference strain from the gene bank (e.g. HSV-1 strain 17 accession no. X14112, HSV-2 strain HG52 accession no. Z86099). Findings suggestive of resistance include frameshift mutations, extra stop codons and non-synonymous nucleotide substitutions in conserved and functionally important gene regions. Interpretation of amino acid substitutions outside of active or conserved gene regions requires access to a data bank in which all resistance mutations described in the literature are pooled [56]. HSV-1 and HSV-2 resistance to acyclovir/ valacyclovir/famciclovir is almost always associated with nonsynonymous mutations of the TK gene and only rarely the DNA polymerase gene, while resistance to foscarnet/cidofovir is exclusively associated with mutations to the DNA polymerase gene. Matching of resistance pheno- and genotypes of HSV isolates is the most reliable and practical method available for confirming the resistance associations of new, as yet unknown amino acid substitutions. The essential advantage of genotyping is that direct testing of patient samples is performed, making virus isolation in cell culture unnecessary. Depending on virus load results may be available within two days, which is of immense importance for clinical decision-making.

\section{Prophylaxis \\ $\nabla$}

\section{Vaccination}

The question of possible immunisation is often raised not only by doctors but also by many patients affected by herpes genitalis. To date, however, there is no licensed vaccine against herpes genitalis, though research has been ongoing for a number of decades. "Therapeutic" vaccines are differentiated from "prophylactic" vaccines depending on their modes of action. Whereas therapeutic vaccines aim to prevent recurrent HSV infections and asymp- 
tomatic viral shedding in people with latent HSV infection, prophylactic vaccines are intended to prevent primary infection and subsequent virus latency. Here HSV-2 has been the main focus of research. A large number of vaccines have been tested in vaginal animal models (mouse and guinea pig) [60], though currently vaccines based on recombinant viral proteins appear to be the most promising [61]. Randomised placebo-controlled trials of adjuvant HSV-2 protein subunit vaccines $[62,63]$ and live attenuated HSV-2 deletion mutants $[64,65]$ in humans have not produced results convincing enough to justify the licensing of a vaccine. Although these vaccines are not associated with a risk of vaccine virus infection and latency, there have been significant difficulties in meaningfully reducing the number of recurrences and preventing primary genital infection with both HSV-1 and $\mathrm{HSV}-2$. There is hope in the knowledge that protection from primary infection is chiefly mediated by virus-specific antibodies, while cell-mediated immunity is of greatest importance in the prevention of recurrence $[60,66]$. Thus vaccine-induced cellular immunity must be stronger than that following natural HSV infection.

\section{Other methods}

Sound, comprehensive partnership counselling is an essential component of the medical management of herpes genitalis patients. For this, HSV type-specific serology is an important tool as it allows identification of the HSV-2 carrier. If no HSV-2-specific antibodies can be detected in the partner of an HSV-2 seropositive person the couple should be advised to use condoms [67]. If herpes genitalis symptoms are present sexual intercourse should be discouraged [68]. Since these measures are particularly important for the prevention of viral transmission during pregnancy both partners should be informed about their HSV serostatus and the possible consequences of viral transmission, both with symptomatic herpes genitalis and asymptomatic viral shedding. Psychotherapy can help reduce the number of herpes genitalis recurrences in women with high levels of emotional stress.

In future microbicides in the form of gels, creams or lotions may be an option for the prevention of herpes virus transmission via sexual intercourse. The best studied substance for this method of herpes genitalis prevention is tenofovir, a nucleoside analogue reverse transcriptase inhibitor licensed for treatment of HIV infection. Studies have shown that vaginal application of tenofovir gel 12 hours before sexual intercourse prevents HSV-2 infection in HSV-2-negative women [69] but does not prevent asymptomatic viral shedding or genital symptoms in women with known herpes genitalis [70]. VivaGel ${ }^{\circledR}$ is another promising microbicide that inhibits HSV replication following vaginal application. This product contains the nanotechnologically manufactured dendrimer SPL7013 as its active substance [71]. However, at best these microbicides will constitute supplementary options for future herpes genitalis prevention.

\section{Practical Conclusions}

$\nabla$

The medical management of patients with herpes genitalis is often unsatisfactory. It can be significantly improved through competent patient counselling and correct implementation of existing methods of diagnosis, treatment and prevention. Nevertheless currently available antiviral treatment and prophylaxis still has shortcomings, especially in the management of frequent recurrences. A new drug class - the helicase blockers - and the development of effective vaccines are expected to improve the situation significantly in future.

\section{Conflict of Interest}

None.

\section{References}

1 King AM, Adams MJ, Carstens EB, Lefcowitz EJ, Hrsg. Virus Taxonomy. Ninth Report of the International Committee on Taxonomy of Viruses. San Diego, CA: Elsevier Academic Press; 2012: 99-124

2 Bergström T, Trybala E. Antigenic differences between HSV-1 and HSV-2 glycoproteins and their importance for type-specific serology. Intervirology 1996; 39: 176-184

3 Scheper T, Saschenbrecker S, Steinhagen K et al. The glycoproteins C and $\mathrm{G}$ are equivalent target antigens for the determination of herpes simplex virus type 1-specific antibodies. J Virol Methods 2010; 166: 42-47

4 Sauerbrei A, Schmitt S, Scheper T et al. Seroprevalence of herpes simplex virus type 1 and type 2 in Thuringia, Germany, 1999 to 2006. Euro Surveill 2011; 16: pii: 20005

5 Wutzler P, Doerr HW, Färber I et al. Seroprevalence of herpes simplex virus type 1 and type 2 in selected German populations-relevance for the incidence of genital herpes. J Med Virol 2000; 61: 201-207

6 Smith JS, Robinson NJ. Age-specific prevalence of infection with herpes simplex virus types 2 and 1: a global review. J Infect Dis 2002; 186 (Suppl. 1): S3-S28

7 Langenberg AG, Corey L, Ashley RL et al. A prospective study of new infections with herpes simplex virus type 1 and type 2. Chirion HSV Vaccine Study Group. N Engl J Med 1999; 341: 1432-1438

8 Roberts CM, Pfister JR, Spear SJ. Increasing proportion of herpes simplex virus type 1 as a cause of genital herpes infection in college students. Sex Transm Dis 2003; 30: 797-800

9 Peña KC, Adelson ME, Mordechai $E$ et al. Genital herpes simplex virus type 1 in women: detection in cervicovaginal specimens from gynecological practices in the United States. J Clin Microbiol 2010; 48: 150153

10 Freeman EE, Weiss HA, Glynn JR et al. Herpes simplex virus 2 infection increases HIV acquisition in men and women: systematic review and meta-analysis of longitudinal studies. AIDS 2006; 20: 73-83

11 Bernstein DI, Bellamy AR, Hook EW 3rd et al. Epidemiology, clinical presentation, and antibody response to primary infection with herpes simplex virus type 1 and type 2 in young women. Clin Infect Dis 2013; 56: 344-351

12 Corey L, Adams HG, Brown ZA et al. Genital herpes simplex virus infections: clinical manifestations, course, and complications. Ann Intern Med 1983; 98: 958-972

13 Stevens JG, Cook ML. Latent herpes simplex virus in spinal ganglia of mice. Science 1971; 173: 843-845

14 Perna JJ, Mannix ML, Rooney JF et al. Reactivation of latent herpes simplex virus infection by ultraviolet light: a human model. J Am Acad Dermatol 1987; 17: 473-478

15 Rand KH, Hoon EF, Massey JKet al. Daily stress and recurrence of genital herpes. Arch Intern Med 1990; 150: 1889-1893

16 Bennedetti J, Corey L, Ashley R. Recurrence rates in genital herpes after symptomatic first-episode infection. Ann Intern Med 1994; 121: 847854

17 Engelberg R, Carrell D, Krantz E et al. Natural history of genital herpes simplex virus type 1 infection. Sex Transm Dis 2003; 30: 174-177

18 Gupta R, Warren T, Wald A. Genital herpes. Lancet 2007; 370: 2127 2137

19 Whitley RJ, Roizman B. Herpes simplex virus infections. Lancet 2001; 357: $1513-1518$

20 Catotti DN, Clarke P, Catoe KE. Herpes revisited. Sex Transm Dis 1993; 20: $77-80$

21 Hofstetter AM, Rosenthal L, Stanberry LR. Current thinking on herpes genitalis. Curr Opin Infect Dis 2014; 27: 75-83

22 Sauerbrei A. Herpes-simplex-Virusinfektionen. In: DVV, GfV, Hrsg. S2kLeitlinie Labordiagnostik schwangerschaftsrelevanter Virusinfektionen. Berlin, Heidelberg: Springer; 2014: 145-157

23 Anzivino E, Fioriti D, Mischitelli $M$ et al. Herpes simplex virus infection in pregnancy and in neonate: status of art of epidemiology, diagnosis, therapy and prevention. Virol J 2009; 6: 40 
24 Sauerbrei $A$, Wutzler P. Herpes simplex and varicella-zoster virus infections during pregnancy - current concepts of prevention, diagnosis and therapy. Part 1: Herpes simplex virus infections. Med Microbiol Immunol 2007; 196: 89-94

25 Rudnick CM, Hoekzema GS. Neonatal herpes simplex virus infections. Am Fam Physician 2002; 6: 1138-1142

26 Corey L, Wald A. Maternal and neonatal HSV infections. N Engl J Med 2009; 361: 1376-1385

27 Kohl S. Neonatal herpes simplex virus infection. Clin Perinatol 1997; 24: $129-150$

28 Deutsche STI-Gesellschaft. S1-Leitlinie STI/STD - Beratung, Diagnostik und Therapie. Online: http://www.awmf.org/uploads/tx_szleitlinien/ 059-0061_S1_STI_STD-Beratung_2015-07.pdf; last access: 22.06.2016

29 Sauerbrei A, Eichhorn $U$, Hottenrott $G$ et al. Virological diagnosis of herpes simplex encephalitis. J Clin Virol 2000; 17: 31-36

30 LeGoff J, Péré H, Bélec L. Diagnosis of genital herpes simplex virus infection in the clinical laboratory. Virol J 2014; 11: 83

31 Workowski KA, Bolan GA; Centers for Disease Control and Prevention. Sexually transmitted diseases treatment guidelines, 2015. MMWR Recomm Rep 2015; 64: 1-137

32 Patel R, Alderson S, Geretti A et al. European guideline for the management of genital herpes, 2010. Int J STD AIDS 2011; 22: 1-10

33 Wald A, Huang ML, Carrell D et al. Polymerase chain reaction for detection of herpes simplex virus (HSV) DNA on mucosal surface: comparison with HSV isolation in cell culture. J Infect Dis 2003; 188: 1345-1351

34 Sauerbrei A, Eichhorn U, Schacke M et al. Laboratory diagnosis of herpes zoster. J Clin Virol 1999; 14: 31-36

35 Wagenlehner FM, Brockmeyer NH, Discher T et al. The presentation, diagnosis and treatment of sexually transmitted infections. Dtsch Arztebl Int 2016; 113: 11-23

36 Swiss Herpes Management Forum. Swiss recommendations for the management of genital herpes and herpes simplex virus infection of the neonate. Swiss Med Wkly 2004; 134: 205-214

37 Brown ZA. Case study: type-specific HSV serology and the correct diagnosis of first-episode genital herpes during pregnancy. Herpes 2002; 9: $24-26$

38 Zahariadis G, Severini A. Evaluation of a novel serology algorithm to detect herpes simplex virus 1 or 2 antibodies. Sex Transm Dis 2010; 37: 696-699

39 Bentley J, Neubauer A, Sauerbrei A. Value of herpes simplex virus typespecific serology: a case report. J Clin Virol 2012; 54: 269-271

40 Hashido M, Inouye S, Kawana T. Differentiation of primary genital herpes infections by a herpes simplex virus-specific immunoglobulin $G$ avidity assay. J Clin Microbiol 1997; 35: 1766-1768

41 Liermann K, Schäfler A, Henke A et al. Evaluation of commercial HSV IgG and IgM enzyme immunoassays. J Virol Methods 2014; 199: 29-34

42 Public Health Agency of Canada. Canadian guidelines on sexually transmitted infections. Section 5 - Management and treatment of specific infections. Genital herpes simplex virus (HSV) infections. Online: http://www.phac-aspc.gc.ca/std-mts/sti-its/cgsti-ldcits/section-5-4eng.php; last access: 11.08 .2016

43 German STI-Society. STI-Treatment Pocket Guide. Online: http://dstig. de/images/DSTIG-Flyer/Leitfaden/sti-treatment\%20pocket\% 20guide_2014.2015_web.pdf; last access: 22.06.2016

44 De Clercq E. Selective anti-herpesvirus agents. Antivir Chem Chemother 2013; 23: 93-101

45 Le Cleach L, Trinquart L, Do G et al. Oral antiviral therapy for prevention of genital herpes outbreaks in immunocompetent and nonpregnant patients (review). Cochrane Database Syst Rev 2014; (8): CD009036

46 Hollier LM, Wendel D. Third trimester antiviral prophylaxis for preventing maternal genital herpes simplex virus (HSV) recurrences and neonatal herpes. Cochrane Database Syst Rev 2008; (1): CD004946

47 Stone KM, Reiff-Eldridge R, White AD et al. Pregnancy outcomes following systemic prenatal acyclovir exposure: conclusions from the international acyclovir pregnancy registry, 1984-1999. Birth Defects Res Clin Mol Teratol 2004; 70: 201-207

48 Pasternak B, Hviid A. Use of acyclovir, valacyclovir, and famciclovir in the first trimester of pregnancy and the risk of birth defects. JAMA 2010; 304: 859-866

49 Kang SH, Chua-Gocheco A, Einarson A. Safety of antiviral medication for the treatment of herpes during pregnancy. Can Fam Physician 2011; 57: 427-428
50 Danve-Szatanek C, Aymard M, Thouvenot D et al. Surveillance network for herpes simplex virus resistance to antiviral drugs: 3-year followup. J Clin Microbiol 2004; 42: 242-249

51 Reyes M, Shaik NS, Graber JM et al. Acyclovir-resistant genital herpes among persons attending sexually transmitted disease and human immunodeficiency virus clinics. Arch Intern Med 2003; 163: 76-80

52 Patel R, Green J, Clarke E et al. 2014 UK national guideline for the management of anogenital herpes. Int J STD AIDS 2015; 26: 763-776

53 Wald A, Corey L, Timmler B et al. Helicase-primase inhibitor pritelivir for HSV-2 infection. N Engl J Med 2014; 370: 201-210

54 Collot M, Rouard C, Brunet C et al. High conservation of herpes simplex virus UL5/UL52 helicase-primase complex in the era of new antiviral therapies. Antiviral Res 2016; 128: 1-6

55 Balfour HH jr., Benson C, Braun J et al. Management of acyclovir-resistant herpes simplex and varicella-zoster virus infections. J Acquir Immune Defic Syndr 1994; 7: 254-260

56 Sauerbrei A, Bohn-Wippert K, Kaspar $M$ et al. Database on natural polymorphisms and resistance-related non-synonymous mutations in thymidine kinase and DNA polymerase genes of herpes simplex virus type 1 and 2. J Antimicrob Chemother 2016; 71: 6-16

57 Morfin F, Thouvenot $D$. Herpes simplex virus resistance to antiviral drugs. J Clin Virol 2003; 26: 29-37

58 Schmidt S, Bohn-Wippert K, Zell R et al. Sequence analysis of herpes simplex virus type 1 thymidine kinase and DNA polymerase genes from over 300 clinical isolates from 1973-2014 finds novel mutations which may be relevant for development of antiviral resistance. Antimicrob Agents Chemother 2015; 59: 4938-4945

59 Safrin S, Crumpacker C, Chatis P et al. A controlled trial comparing foscarnet with vidarabine for acyclovir-resistant mucocutaneous herpes simplex in the acquired immunodeficiency syndrome. N Engl J Med 1991; 325: 551-555

60 Awasthi S, Friedman M. Status of prophylactic and therapeutic genital herpes vaccines. Curr Opin Virol 2014; 6: 6-12

61 Odegard JM, Flynn PA, Campbell DJ et al. A novel HSV-2 subunit vaccine induces GLA-dependent CD4 and CD8 T cell responses and protective immunity in mice and guinea pigs. Vaccine 2016; 34: 101-109

62 Straus SE, Corey L, Burke RL et al. Placebo-controlled trial of vaccination with recombinant glycoprotein $D$ of herpes simplex virus type 2 for immunotherapy of genital herpes. Lancet 1994; 343: 1460-1463

63 Straus SE, Wald A, Kost RK et al. Immunotherapy of recurrent genital herpes with recombinant herpes simplex virus type 2 glycoprotein $D$ and B. results of a placebo-controlled vaccine trial. J Infect Dis 1997; 176: $1129-1134$

64 Casanova G, Cancela R, Alonzo L et al. A double-blind study of the efficacy and safety of the ICP10deltaPK vaccine against recurrent genital HSV-2 infections. Cutis 2002; 70: 235-239

65 deBruyn $G$, Vargas-Cortez M, Warren T et al. A randomized controlled trial of a replication defective (gH deletion) herpes simplex virus vaccine for the treatment of recurrent genital herpes among immunocompetent subjects. Vaccine 2006; 24: 914-920

66 Halford WP, Geltz J, Messer RJ et al. Antibodies are required for complete vaccine-induced protection against herpes simplex virus 2 . PLoS One 2015; 10: e0145228

67 Stanaway JD, Wald A, Martin ET et al. Case-crossover analysis of condom use and herpes simplex virus type 2 acquisition. Sex Transm Dis 2012; 39: 388-393

68 Gottlieb SL, Douglas JM jr., Foster $M$ et al. Incidence of herpes simplex virus type 2 infection in 5 sexually transmitted disease (STD) clinics and the effect of HIV/STD risk-reduction counselling. J Infect Dis 2004; 15: 1059-1067

69 Abdool Karim SS, Abdool Karim Q Kharsany AB et al. Tenofovir gel for the prevention of herpes simplex virus type 2 infection. N Engl J Med 2015; 373: 530-539

70 Bender Ignacio RA, Perti T, Magaret AS et al. Oral and vaginal tenofovir for genital herpes simplex virus type 2 shedding in immunocompetent women: a double-blind, randomized, cross-over trial. J Infect Dis 2015; 212: 1949-1956

71 Price CF, Tyssen D, Sonza S et al. SPL7013 Gel (VivaGel $\left.{ }^{\circledR}\right)$ retains potent HIV-1 and HSV-2 inhibitory activity following vaginal administration in humans. PLoS One 2011; 6: e24095 